\title{
A new species of nucleo-cytoplasmic large DNA virus (NCLDV) associated with mortalities in Manitoba lake sturgeon Acipenser fulvescens
}

\author{
Sharon C. Clouthier ${ }^{1, *}$, Elissa VanWalleghem ${ }^{1,2}$, Shelagh Copeland ${ }^{3}$, Cheryl Klassen ${ }^{2}$, \\ Gary Hobbs ${ }^{4}$, Ole Nielsen ${ }^{1}$, Eric D. Anderson ${ }^{5}$ \\ ${ }^{1}$ Freshwater Institute, Fisheries \& Oceans Canada, 501 University Crescent, Winnipeg, Manitoba R3T 2N6, Canada \\ ${ }^{2}$ Department of Biological Sciences, University of Manitoba, Winnipeg, Manitoba R3T 2N2, Canada \\ ${ }^{3}$ Manitoba Agriculture, Food and Rural Initiatives, Veterinary Diagnostic Services, 545 University Crescent, Winnipeg, \\ Manitoba R3T 5S6, Canada \\ ${ }^{4}$ Manitoba Conservation and Water Stewardship, Ecological Services Division, Grand Rapids, Manitoba R0C 1E0, Canada \\ ${ }^{5}$ Box 28, Group 30, RR2, Ste. Anne, Manitoba R5H 1R2, Canada
}

\begin{abstract}
A newly discovered virus, Namao virus, associated with morbidity and mortality, was detected among juvenile lake sturgeon Acipenser fulvescens being propagated by a conservation stocking program for this endangered species in Manitoba, Canada. The outbreaks resulted in cumulative mortalities of 62 to $99.6 \%$ among progeny of wild Winnipeg River or Nelson River lake sturgeon and occurred at 2 geographically separate facilities. Namao virus was detected in almost $94 \%$ of the moribund or dead lake sturgeon according to a conventional polymerase chain reaction (CPCR) test that is based upon amplification of a $219 \mathrm{bp}$ fragment of the virus major capsid protein (MCP). The virus itself was large (242 to $282 \mathrm{~nm}$ ) and icosahedral-shaped with 2 capsids and a condensed bar-shaped core. It was found in virus factories within the host cell cytoplasm and displayed a tropism for the integument. Namao virus caused cellular changes characterized by enlarged eosinophilic epithelial cells in the gills and skin. Samples suspected of containing Namao virus did not have cytopathic effects on primary lake sturgeon or established white sturgeon cell lines. However, viral nucleic acid was detected in the former after prolonged incubation periods. Using primers designed from conserved regions of the MCP from NCLDVs, an estimated 95 to $96 \%$ of the Namao virus MCP open reading frame was captured. Phylogenetic analysis using the MCP of Namao virus and 27 other NCLDVs suggested that Namao virus and white sturgeon iridovirus share a common evolutionary past and might be members of the family Mimiviridae or a new, as yet unrecognized, virus family.
\end{abstract}

KEY WORDS: Namao virus $\cdot$ Mimiviridae $\cdot$ Endangered species

Resale or republication not permitted without written consent of the publisher

\section{INTRODUCTION}

Viruses classified within the families Mimiviridae, Phycodnaviridae and Iridoviridae as well as the Marseillevirus and megaviruses are a ubiquitous component of the aquatic environment (Chen et al. 1996, Fuhrman 1999, Monier et al. 2008, Van Etten et al. 2010). Along with members of the families Poxviridae and Ascoviridae, they form a putative monophyletic class of viruses referred to as nucleo-cytoplasmic large DNA viruses (NCLDVs; Table 1) (Iyer et al. 2001, 2006, Koonin \& Yutin 2010). A common ancestral virus is suggested to have possessed a set of at least 47 conserved genes that can be mapped onto the genomes of extant NCLDVs (Koonin \& Yutin 2010). As a group, they share 5 common protein- 
Table 1. Members of the nucleo-cytoplasmic large DNA virus (NCLDV) super-family

\begin{tabular}{|lccc|}
\hline Virus taxon & Host range & $\begin{array}{c}\text { Genome } \\
\text { size (kb) }\end{array}$ & $\begin{array}{c}\text { Capsid } \\
\text { diameter (nm) }\end{array}$ \\
\hline Iridoviridae & & $100-220$ & $120-350$ \\
Ascoviridae & Insects, cold blooded vertebrates & $150-190$ & 130 \\
Asfarviridae & Insects, mainly Noctuids & $170-190$ \\
Poxviridae & Mammals & $130-380$ & 200 \\
Phycodnaviridae & Insects, reptiles, birds, mammals & $130-200$ \\
Marseillevirus & Green algae, algal symbionts of paramecia \& hydras & 1500 & 250 \\
Mimiviridae & Amoeba & 370 \\
CroV & & 730 & 300 \\
Mimivirus & Marine microzooplankton & 1181 & $390-400$ \\
Mamavirus & Amoeba & 1191 & Not available \\
Megaviruses & Amoeba & 440 \\
Sturgeon viruses & Unknown & Unknown & $225-263$ \\
Namao virus (NV) & & Unknown & 262 \\
White sturgeon iridovirus (WSIV) & Lake sturgeon & Unknown & 254 \\
Missouri River sturgeon iridovirus (MRSIV) & Pallid and shovelnose sturgeon & Unknown \\
Russian sturgeon iridovirus (RSIV) & Russian sturgeon & 283 \\
\hline
\end{tabular}

coding sequences (CDSs), including the major capsid protein (MCP), with an additional 177 shared by 2 or more families within the NCDLV super-family (Yutin et al. 2009).

NCLDVs replicate in the cytoplasm of the host cell or start their life cycle in the host nucleus and complete it in the cytoplasm (Iyer et al. 2001, 2006, Koonin \& Yutin 2010). They share common biophysical characteristics such as complex, isometric virion structures (120 to $440 \mathrm{~nm}$ ) and very large double-stranded DNA genomes $(0.1$ to $1.3 \mathrm{Mb}$ ) (Table 1$)$. The number of CDSs of many NCLDVs exceeds that of the smallest free-living bacteria Mycoplasma genitalium ( 470 CDS, Claverie et al. 2006). The large repertoire of genes encoding proteins involved in DNA replication, processing, maturation and packaging, transcription initiation and elongation as well as capsid proteins and chaperones for assembly provide NCLDVs with relative autonomy from the host cell. It is perhaps not surprising that they can have diverse, complex life-cycles and a broad host range that includes amoeba, algae, insects, reptiles, birds, mammals, and fish (Van Etten et al. 2010, Van Etten 2011).

Several NCLDVs of sturgeon (Acipenseridae) hitherto recognized as unclassified members of the family Iridoviridae, pose a potential disease risk for strategies designed to aid the recovery of threatened sturgeon populations in North America. These include the white sturgeon iridovirus (WSIV), found in wild and cultured white sturgeon Acipenser transmontanus (Hedrick et al. 1990, LaPatra et al. 1994, Raverty et al. 2003), as well as the Missouri River sturgeon iridovirus (MRSIV), which has been isolated from pallid stur- geon Scaphirhynchus albus and shovelnose sturgeon S. platorynchus (Kurobe et al. 2010, 2011).

Sturgeon NCLDVs can assume a complex lifecycle. In some instances they cause upwards of $95 \%$ mortality within captive populations whereas in others they are associated with a chronic debilitating wasting syndrome, resulting in severely impaired growth and reduced survival of fry and fingerlings (Hedrick et al. 1990, LaPatra et al. 1994, Kurobe et al. 2011). Outbreaks of viral disease in white sturgeon as well as pallid or shovelnose sturgeon are typically observed during the first year of growth in hatcheries (Hedrick et al. 1990, 1992, Kurobe et al. 2011). Adults can be refractory to clinical disease, but are likely subclinical carriers that may intermittently shed virus (Hedrick et al. 1990, LaPatra et al. 1994, Kurobe et al. 2011). Horizontal transmission of WSIV and MRSIV from convalescent to naïve juvenile sturgeon has been demonstrated (Hedrick et al. 1990, Drennan et al. 2006, Kurobe et al. 2011) and there are suggestions that egg-associated transmission from adult to offspring occurs during spawning (Hedrick et al. 1992, LaPatra et al. 1994, Georgiadis et al. 2001). Handling, stocking density and fluctuations in water levels, flow rates, and/or temperature are among the other risk factors known to contribute to the onset and severity of these disease outbreaks (LaPatra et al. 1994, 1996, Watson et al. 1998a, Georgiadis et al. 2000, 2001, Drennan et al. 2005, 2006).

WSIV and MRSIV have historically been diagnosed using a combination of histology and electron microscopy. Both viruses localize to the integument of the oropharynx and olfactory organs as well as the 
fins and in some cases the epithelium of the gills (Hedrick et al. 1990, Watson et al. 1998b, Drennan et al. 2007, Kurobe et al. 2011). Microscopic signs of infection include hypertrophied, basophilic or amphophilic- to eosinophilic-staining cells and eccentric nuclei, as well as inclusion bodies containing isometric, doubly encapsidated virus particles displaying a condensed bar-shaped nucleoid (Hedrick et al. 1990, 1992, Kurobe et al. 2011). A number of white sturgeon cell lines have been developed that are permissive to WSIV amplification but in an isolate-specific manner and sometimes without evidence of cytopathic effect (CPE) (Hedrick et al. 1991, Watson et al. 1998b). These as well as pallid and shovelnosederived cell lines do not support the growth of MRSIV (Kurobe et al. 2011). More recently, conven-

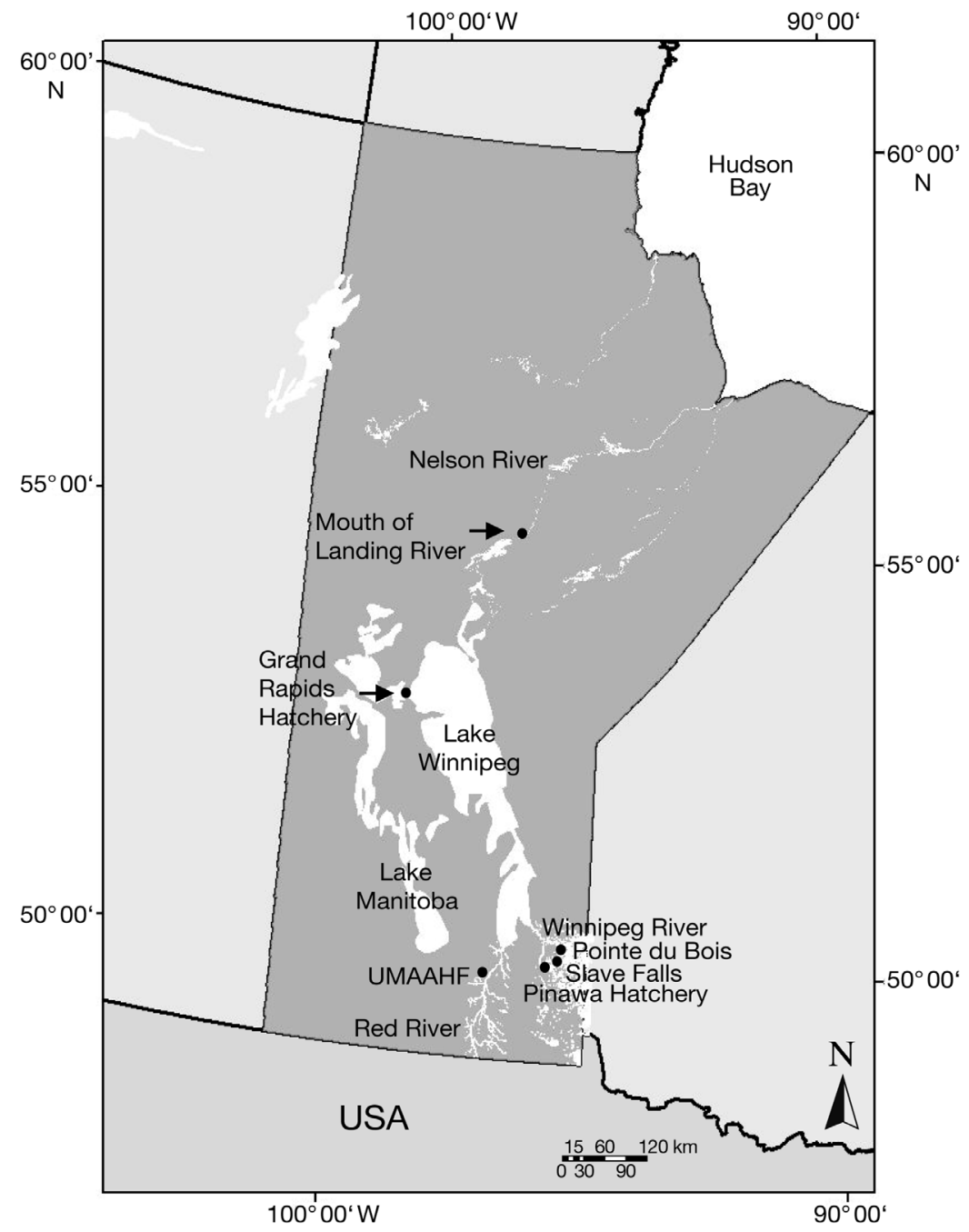

Fig. 1. Location of rivers in Manitoba (dark grey shading), Canada where wild lake sturgeon Acipenser fulvescens broodstock were collected and hatcheries where progeny were held. UMAAHF: University of Manitoba Aquatic Animal Holding Facility tional (cPCR) and/or quantitative PCR (qPCR) assays have been developed to detect WSIV or MRSIV. The current white sturgeon end-point or qPCR assays target viral DNA encoding the MCP (Kwak 2006, Kwak et al. 2006) which is one of the 5 orthologous DNA sequences common to NCLDVs (Yutin et al. 2009), while the MRSIV qPCR assay is based on amplification of DNA encoding the serpin protein (Kurobe et al. 2010). Neither of these assays is capable of detecting viral DNA from the aforementioned NCLDV found in Manitoba lake sturgeon.

In this paper we provide the first description of a new NCLDV found in populations of Manitoba (MB) lake sturgeon Acipenser fulvescens, a species classified as endangered by the Committee on the Status of Endangered Wildlife in Canada (COSEWIC 2011). Further, we provide evidence of a new NCLDV lineage comprised of these sturgeon viruses and discuss their phylogenetic relationship to other viruses in the NCLDV clade.

\section{MATERIALS AND METHODS}

\section{Case history}

Unusual mortalities occurred in groups of juvenile lake sturgeon reared at the Grand Rapids Hatchery (GRH) (Grand Rapids, MB) and the University of Manitoba Aquatic Animal Holding Facility (UMAAHF) (Winnipeg, MB) (Fig. 1) in 2009 and 2010.

The lake sturgeon reared at UMAAHF were derived from multiple crosses of eggs and sperm collected from sexually mature, wild Winnipeg River (MB) lake sturgeon (16 males, 8 females) captured at Slave Falls in May 2008. The fertilized eggs were hatched at the temporary Pinawa Hatchery (Pinawa, MB) and the fry (15 to $20 \mathrm{~mm}$ in length) were subsequently transported on June 12, 2008 to UMAAHF. Tissue samples were collected for diagnostic evaluation on December 7, 9, 11 and 17, 2008 from 7 apparently healthy lake sturgeon housed in 6 different tanks. On December 22, 2008, after a series of transfers to successively larger tanks, approximately 1758 lake sturgeon (mean body weight $5.7 \mathrm{~g}$, length not recorded) were placed in four 
600 gallon tanks receiving de-chlorinated $16^{\circ} \mathrm{C} \mathrm{mu-}$ nicipal water at 1 to $21 \mathrm{~min}^{-1}$. In February 2009, mortalities occurred amongst 606 lake sturgeon (mean body weight $3.0 \mathrm{~g}$, cumulative percent mortality [CPM] 64\%) held in Tank 600-1 (Fig. 2A). Then in May 2009, mortalities were observed in Tanks 600-3, 600-4 and 600-5 stocked with 569, 195 and 388 lake sturgeon (mean body weight $19.3 \mathrm{~g}$, mean fork length $174 \mathrm{~mm})$, respectively. CPM in these 3 tanks ranged from 62 to $99 \%$. Tissue samples from dead or moribund fish were submitted for diagnostic evaluation.

The GRH received fertilized eggs derived from wild Nelson River (MB) lake sturgeon (6 males, 4 females) on June 15, 2009 and fry from wild Winnipeg River (Pointe du Bois) lake sturgeon (17 males, 5 fe-

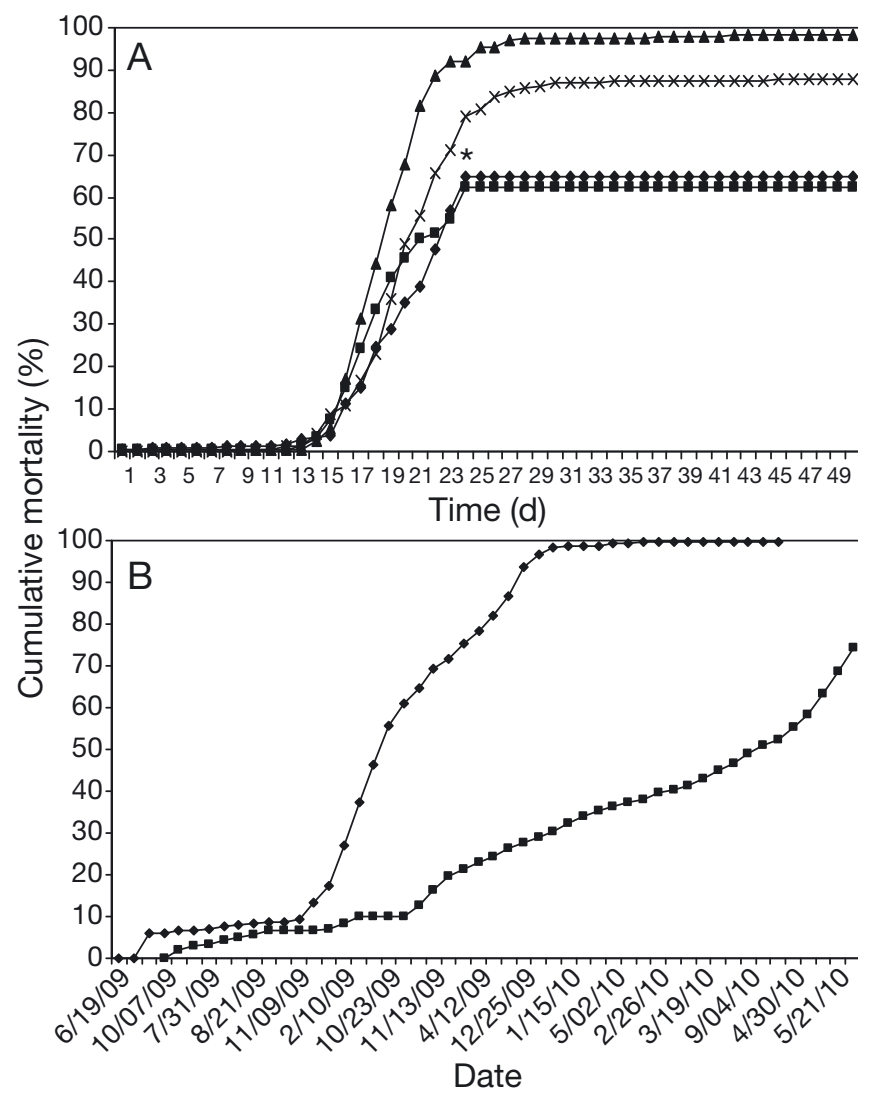

Fig. 2. Acipenser fulvescens. Cumulative mortality among juvenile lake sturgeon. (A) Sturgeon held at University of Manitoba Aquatic Animal Holding Facility: progeny (2008 year class) from wild Winnipeg River broodstock collected at Slave Falls. Time zero was normalized to $16 \mathrm{~d}$ prior to onset of significant mortality within each of 4 tanks: ( $\bullet$ Tank 600-1, Day 16 = Feb 11, 2009; (घ) Tank 600-3, Day 16 = May 9, 2009; (ム) Tank 600-4, Day 16 = May 27, 2009; (×) Tank 600-5, Day 16 = May 12, 2009. (*) Date when fish remaining in tanks 600-1 and 600-3 were removed. (B) Sturgeon held at Grand Rapids Hatchery: progeny (2009 year class) from $(\bullet)$ feral Nelson River broodstock collected near Landing River and (घ) Winnipeg River broodstock collected at Pointe du Bois males) on July 9, 2009. The 2 populations of fish were held separately in long, shallow troughs $(\mathrm{L} \times \mathrm{W} \times \mathrm{D} \approx$ $3.7 \times 5.2 \times 3.1 \mathrm{~m}$ ) receiving untreated, ambient temperature surface water from the Saskatchewan River (Cross Bay, Cedar Lake) (average temperature $10.1^{\circ} \mathrm{C}$ June through September, $4.9^{\circ} \mathrm{C}$ October through May). Mortalities began to increase among approximately 1974 Nelson River lake sturgeon (Nov 4, 2009: mean body weight $17.3 \mathrm{~g}$, mean fork length $15.5 \mathrm{~cm}$ ) in late September 2009 and reached CPM of 99.6\% by February 19, 2010 (Fig. 2B). Similarly, mortalities began to increase among approximately 14608 Winnipeg River lake sturgeon (mean body weight $11 \mathrm{~g}$, mean fork length $13.9 \mathrm{~cm}$ ) in early November 2009 and reached a CPM of $74 \%$ on May 28, 2010 at which time the remaining fish were euthanized. Tissue samples were submitted from each group of lake sturgeon for diagnostic evaluation.

The UMAAHF also received fry derived from the wild Winnipeg River (Pointe du Bois) lake sturgeon broodstock described in the previous paragraph. The fish were received on October 8, 2009 and held in 600 gallon tanks receiving dechlorinated $16^{\circ} \mathrm{C}$ municipal water at 1 to $21 \mathrm{~min}^{-1}$. Sporadic mortality occurred in these tanks throughout 2010 (body weight range 11 to $32 \mathrm{~g}$, lengths not recorded) and tissue samples from dead or moribund fish were submitted for diagnostic evaluation.

\section{Bacteriology, virology, histology and electron microscopy}

Gill, spleen and kidney tissues from a small number of dead or moribund juvenile lake sturgeon collected during the mortality events at UMAAHF ( $\mathrm{n}=$ 10, Winnipeg River stock) or GRH ( $\mathrm{n}=15$; 10 Winnipeg River stock, 5 Nelson River stock) were tested for the presence of bacteria by inoculation of tryptic soy agar (TSA) supplemented with 5\% sheep blood and MacConkey agar followed by incubation at $22^{\circ} \mathrm{C}$ and $35^{\circ} \mathrm{C}$ under aerobic as well as anaerobic conditions. Gill tissue was also used to inoculate chocolate agar as well as TSA containing $5 \%$ sheep blood followed by incubation in a $\mathrm{CO}_{2}$ candle jar at $22^{\circ} \mathrm{C}$ and $35^{\circ} \mathrm{C}$. Further, skin, gill and intestinal wet mounts as well as Gram stains of kidney and gill smears were performed on samples from 8 fish from UMAAHF (Winnipeg River stock) and 15 fish from GRH (10 Winnipeg River stock, 5 Nelson River stock).

Barbells, gill arches, operculum, head skin, anal and/or pectoral fins as well as kidney, liver, spleen and/or pyloric caeca tissues were aseptically collected 
from 33 Winnipeg River and 15 Nelson River lake sturgeon and held at $4{ }^{\circ} \mathrm{C}$ prior to analyses by virology on epithelioma papulosum cyprini (EPC), Chinook salmon embryo 214 (CHSE-214), white sturgeon skin (WSSK-1), white sturgeon spleen (WSS-2), lake sturgeon gill (LSGI) and/or lake sturgeon gonad (LSGO) cell lines (Fijan et al. 1983, Lannan et al. 1984, Hedrick et al. 1991). Some of these samples were also submitted to the British Columbia Freshwater Fisheries Society (BCFFS) (Duncan, British Columbia). Each cell line was propagated at $16^{\circ} \mathrm{C}$ in minimum essential medium with Earle's salts (MEM-E) or Hanks salts (MEM-H) supplemented with $10 \%$ fetal bovine serum (FBS) and $2 \mathrm{mM}$ L-glutamine (Life Technologies). Replicate wells of a 24-well tissue culture plate containing cell monolayers were inoculated with $0.1 \mathrm{ml}$ of a 1:50 dilution of clarified homogenate generated from pools of tissue from a single fish. After an absorption period of $1 \mathrm{~h}, 1 \mathrm{ml}$ of MEM-E or MEM-H supplemented with $2 \%$ FBS (MEM-E2, MEM-H2), 2 mM L-glutamine and $1 \times$ antibiotic/antimycotic (Life Technologies) was added to each well of the plate, the plate was incubated at $16^{\circ} \mathrm{C}$ and the monolayers were observed daily for evidence of CPE. At the time of harvest, each inoculated monolayer was scraped from the bottom of the well into the culture fluid and the cell suspension was transferred to a storage vial and placed at $-80^{\circ} \mathrm{C}$.

In preparation for histological examination, an incision was made in the abdomen of 9 moribund lake sturgeon from the Winnipeg River stock (5 from GRH, 4 from UMAAHF) and 5 from the Nelson River stock and whole fish were placed in $10 \%$ buffered formalin. After 24 to $48 \mathrm{~h}$, portions of the fixed tissues were processed for light microscopy into paraffin embedded blocks, sectioned at $5 \mu \mathrm{m}$, deparaffinized and then stained with hematoxylin and eosin (H\&E).

For transmission electron microscopy (TEM), formalin-fixed gill tissue from a single juvenile Winnipeg River lake sturgeon (MAAHF) was rinsed in buffer and post-fixed in $1 \%$ aqueous osmium tetroxide, dehydrated through a graded ethanol series, infiltrated and then embedded in Araldite 502/ Embed 812 resin. Thin sections (about $100 \mathrm{~nm}$ ) were stained with uranyl acetate and lead citrate prior to being examined using a Philips CM 120 transmission electron microscope at $80 \mathrm{kV}$. Digital imaging was performed with an AMT XR-611 camera system.

\section{Establishment of lake sturgeon cell lines}

Gill and gonad tissues were aseptically removed from 2 juvenile lake sturgeon (52.5 and $62.7 \mathrm{~g}$ ), washed 5 times with sterile phosphate buffered saline (PBS), minced into smaller pieces and then resuspended in $0.25 \%$ porcine trypsin/EDTA (HyClone). Cells were dispersed from the tissue fragments by mechanical agitation for $20 \mathrm{~min}$ at $22^{\circ} \mathrm{C}$. The resulting cell suspension was diluted 1:1 (v/v) with Dulbecco's Modified Eagles Medium (DMEM)/Ham's F12 supplemented with $10 \%$ FBS, 200 IU penicillin and $200 \mu \mathrm{g}$ streptomycin $\mathrm{ml}^{-1}$ (Life Technologies), centrifuged at $1228 \times g$ for $15 \mathrm{~min}$ at $4^{\circ} \mathrm{C}$ and then resuspended in fresh media prior to being transferred to $25 \mathrm{~cm}^{2}$ flasks. The lake sturgeon cell monolayers were propagated at $16^{\circ} \mathrm{C}$ in MEM-H supplemented with $10 \%$ FBS, 2 mM L-glutamine and $2 \times$ antibiotic/antimycotic (Life Technologies).

\section{DNA synthesis and plasmid purification}

DNA representing the gene encoding the WSIV MCP (Genbank accession number DQ897645) was synthesized and ligated into the cloning vector pJ204 (DNA2.0). The construct was then transformed into Escherichia coli DH5 $\alpha$ competent cells and plasmid DNA was purified with a QIAprep Spin Miniprep Kit (Qiagen) according to the manufacturer's instructions.

\section{DNA extraction}

Tissue samples including ventral head skin, abdominal skin, gill arches, barbells, operculum, kidney, liver as well as pectoral and anal fins were collected from dead, moribund or frozen lake sturgeon from mortality events occurring at GRH and UMAAHF. Homogenates of $50 \mathrm{mg}$ portions of these tissues were generated in lysis buffer (Qiagen buffer ATL) using a $5 \mathrm{~mm}$ stainless steel bead (Qiagen) and TissueLyser (Qiagen) operated twice for $2 \mathrm{~min}$ at $30 \mathrm{~Hz}$. DNA was extracted from the tissue homogenates using the DNeasy Blood and Tissue Kit (Qiagen) as outlined by the manufacturer and then quantified using the Nanodrop 8000 .

\section{PCR amplification, cloning and DNA sequence analysis}

DNA samples were tested for the presence of WSIV and MRSIV using qPCR protocols described by Kwak (2006) and Kurobe et al. (2010), respectively. Samples were also submitted to the Animal Health Cen- 
ter (AHC) in Abbotsford, $\mathrm{BC}$ for additional molecular testing.

Primers targeting the Namao virus MCP were designed based on conserved regions identified from sequence alignments of the MCP from representative members of the NCLDV family of viruses (Table 2). Portions of the Namao virus MCP gene were amplified by cPCR using pairwise combinations of the primers listed in Table 3 and DNA was extracted from tissue samples collected from populations of lake sturgeon experiencing mortality at either GRH or UMAAHF. The origin of the amplicon was tested using DNA from Namao virus-infected
Table 3. Oligonucleotides used in the present study for amplification of DNA encoding lake sturgeon Namao virus major capsid protein (partial). Nucleotide positions are shown relative to white sturgeon iridovirus major capsid protein coding region (GenBank accession no. DQ897645)

\begin{tabular}{|lcc|}
\hline Primer & $\begin{array}{c}\text { Sequence } \\
\left(5^{\prime} \text { to } 3^{\prime}\right)\end{array}$ & $\begin{array}{c}\text { Nucleotide } \\
\text { position (bp) }\end{array}$ \\
\hline speF & CCA GAA ATG ACT TAC TTC AAG & 64 \\
ginF & GGT ATC AAC GTA TAT TCG TTT GC & 1369 \\
ginR & GCA AAC GAA TAT ACG TTG ATA CC & 1391 \\
pekR & CCA GAA GGT TGG TGC TTT TCA GG & 1421 \\
glaR & GTA TGC CAG ACC CGC TAG ACC & 1587 \\
\hline
\end{tabular}

Table 2. Major capsid protein of representative members of the nucleo-cytoplasmic large DNA virus (NCLDV) superfamily. Capsid NCLDV domains were identified by the Conserved Domain Database (see 'Materials and methods')

\begin{tabular}{|c|c|c|c|c|c|c|c|}
\hline \multirow{2}{*}{ Virus } & \multirow{2}{*}{$\begin{array}{l}\text { Abbre- } \\
\text { viation }\end{array}$} & \multirow{2}{*}{$\begin{array}{l}\text { Gene } \\
\text { (bp) }\end{array}$} & \multirow{2}{*}{$\begin{array}{l}\text { Protein } \\
\text { (aa) }\end{array}$} & \multirow{2}{*}{$\begin{array}{l}\text { NCLDV } \\
\text { domains }\end{array}$} & \multicolumn{2}{|c|}{ Accession number } & \multirow{2}{*}{ Reference } \\
\hline & & & & & DNA & Protein & \\
\hline \multicolumn{8}{|l|}{ Unclassified mimivirus-like } \\
\hline Namao virus & NV & $\begin{array}{c}1524 \\
\text { partial }\end{array}$ & $\begin{array}{c}508 \\
\text { partial }\end{array}$ & 2 & JX155659 & & Present study \\
\hline White sturgeon iridovirus & WSIV & 1596 & 531 & 2 & DQ897645 & ABK34555.1 & Direct submission \\
\hline \multicolumn{8}{|l|}{ Mimiviridae } \\
\hline $\begin{array}{l}\text { Acanthamoeba polyphaga } \\
\text { mimivirus (Bradford isolate) }\end{array}$ & APMV-1 & 1782 & 593 & 2 & NC 014649.1 & YP003986929 & Legendre et al. (2011) \\
\hline $\begin{array}{l}\text { Acanthamoeba polyphaga } \\
\text { mimivirus (M4 isolate) }\end{array}$ & APMV-2 & 1776 & 591 & 2 & JN036606.1 & AEJ34665.1 & Boyer et al. (2011) \\
\hline Cafeteria roenbergensis virus & CroV & 1521 & 506 & 2 & NC 014637.1 & YP003969975.1 & Fischer et al. (2010) \\
\hline Megavirus chiliensis & MVChile & 1770 & 589 & 2 & NC 016072.1 & YP004894515.1 & Arsian et al. (2011) \\
\hline Megavirus courdo & MVCour & 1698 & 565 & 2 & JN885991.1 & AEX61606 & Direct submission \\
\hline Acanthamoeba castellanii mamavirus & ACMV & 1776 & 591 & 1 & JF801956.1 & AEQ60611.1 & Colson et al. (2011) \\
\hline \multicolumn{8}{|l|}{ Phycodnaviridae } \\
\hline Organic lake phycodnavirus 2 & OLPV-2 & 1611 & 536 & 1 & HQ704803.1 & ADX06358 & Yau et al. (2011) \\
\hline Phaeocystis pouchetii virus & PPV & 1563 & 520 & 1 & EU006631.1 & ABU23715.1 & Larsen et al. (2008) \\
\hline Chrysochromulina ercina virus & CEV & 1755 & 584 & 1 & EU006628.1 & ABU23712.1 & Larsen et al. (2008) \\
\hline Pyramimonas orientalis virus & POV & 1191 & 396 & 1 & EU006630.1 & ABU23714 & Larsen et al. (2008) \\
\hline Heterosigma akashiwo virus & HAV & 1323 & 440 & 1 & AB198422.1 & BAE06835 & Nagasaki et al. (2005) \\
\hline Acanthocystis turfacea chlorella virus & ATCV & 1317 & 438 & 1 & NC 008724.1 & YP001426761.1 & Direct submission \\
\hline Paramecium bursaria chlorella virus & PBCV & 1314 & 437 & 1 & NC 009898.1 & YP001497813.1 & Fitzgerald et al. (2007) \\
\hline Micromonas pusilla virus & MPV & 1257 & 418 & 1 & HQ633072.1 & AET43572 & Direct submission \\
\hline Ostreococcus tauri virus & OTV & 1269 & 422 & 1 & NC013288.1 & YP003495004.1 & Weynberg et al. (2009) \\
\hline Feldmannia spp. virus & FSV & 1308 & 435 & 1 & NC011183.1 & YP002154681.1 & Schroeder et al. (2009) \\
\hline Ectocarpus siliculosus virus & ESV & 1428 & 475 & 1 & FN648730.1 & CBN80416.1 & Cock et al. (2010) \\
\hline \multicolumn{8}{|l|}{ Iridoviridae } \\
\hline Chilo iridescent virus & CIV & 1404 & 467 & 1 & NC003038.1 & NP149737 & Jakob et al. (2001) \\
\hline Invertebrate iridescent virus 3 & IIV3 & 1401 & 466 & 1 & NC008187.1 & YP654586 & Delhon et al. (2006) \\
\hline Frog virus 3 & FV3 & 1392 & 463 & 1 & FJ459783.1 & ACP19256.1 & Holopainen et al. (2009) \\
\hline Infectious spleen and kidney virus & ISKNV & 1362 & 453 & 1 & AF371960.1 & AAL98730.1 & He et al. (2001) \\
\hline Lymphocystis disease virus & LDV & 1380 & 459 & 1 & EF103188.1 & ABL07488.1 & Direct submission \\
\hline \multicolumn{8}{|l|}{ Unclassified } \\
\hline Marseillevirus & MV & 1434 & 477 & 1 & NC013756.1 & YP003407071.1 & Boyer et al. (2009) \\
\hline \multicolumn{8}{|l|}{ Ascoviridae } \\
\hline Diadromus pulchellus ascovirus $4 \mathrm{a}$ & DPAV & 1305 & 434 & 1 & AJ312705.1 & CAC84483.1 & Stasiak et al. (2003) \\
\hline \multicolumn{8}{|l|}{ Asfarviridae } \\
\hline African swine fever virus & ASFV & 1941 & 646 & 1 & XM369245.2 & XP369245.2 & Direct submission \\
\hline
\end{tabular}


lake sturgeon tissue, naïve lake sturgeon tissue as well as white and lake sturgeon cell lines. Each $25 \mu \mathrm{l}$ reaction contained $1 \times$ PCR buffer (Applied Biosystems), $1.5 \mathrm{mM} \mathrm{MgCl}_{2}, 200 \mu \mathrm{M}$ deoxynucleoside triphosphates, 1.25 U AmpliTaq Gold DNA polymerase (Applied Biosystems), $0.8 \mu \mathrm{M}$ of each primer and between 100 to $500 \mathrm{ng}$ of DNA. Thermocycling parameters were as follows: $95^{\circ} \mathrm{C}$ for $5 \mathrm{~min}, 40$ cycles of $\left(95^{\circ} \mathrm{C}\right.$ for $30 \mathrm{~s}, 52$ or $53^{\circ} \mathrm{C}$ for $30 \mathrm{~s}, 72^{\circ} \mathrm{C}$ for 1 or $1.5 \mathrm{~min}$ ) followed by a post-cycle extension at $72^{\circ} \mathrm{C}$ for $10 \mathrm{~min}$.

Amplicons generated from 25 to $50 \mu$ of the cPCR product were analyzed for purity and size by electrophoresis in $1 \%$ agarose gels, purified with the QIAquick Gel Extraction Kit (Qiagen) as outlined by the manufacturer and then TA cloned into vector pGEM-T Easy (Promega). Plasmid DNA was isolated from cultures of transformed E. coli as outlined above and screened for inserts by cPCR using the relevant primer pairs. Both strands of DNA from at least 3 positive clones per amplicon were sequenced by the dideoxynucleotide chain termination method using an automated sequencer (Sanger et al. 1977). Analyses of the DNA sequences were performed using BioEdit v7.0.9.0 software (Hall 1999).

\section{BLASTP, sequence alignment and phylogenetic analysis}

Sequences displaying similarity to the deduced amino acid sequence of the partial Namao virus MCP were identified from protein databases searched using the BLASTP program (Altschul et al. 1990, 1997). Protein sequence alignments were performed using T-Coffee (Notredame et al. 2000, Di Tommaso et al. 2011) with sequences that were trimmed to the first amino acid aligning with the $\mathrm{N}$ terminal end of the Namao virus MCP fragment and the last amino acid at the $\mathrm{C}$ terminal end. A percent identity and similarity matrix for the trimmed $\mathrm{MCP}$ sequences was created using the Matrix Global Alignment Tool (MatGAT 2.02) software (Campanella et al. 2003). Conserved domains in the truncated protein sequences were annotated through the Conserved Domain Database using the National Center for Biotechnology Information's (NCBI) Conserved Domain Search service (Marchler-Bauer et al. 2011).

Phylogenetic tree reconstructions were estimated by 2 methods: Bayesian inference analysis as implemented by MRBAYES v3.2.1 (Huelsenbeck \& Ronquist 2001, Ronquist \& Huelsenbeck 2003) and maximum-likelihood as implemented by PHYML 3.69
(Guindon et al. 2010). The Bayesian trees were estimated using multiple independent runs of aamodelpr = mixed and default settings for 1500000 generations when the average deviation of the split frequencies was $<0.002$. For maximum-likelihood trees, clade confidences were estimated from 1000 bootstrap replicates. The output tree produced from each method was visualized using FigTree v1.3.1 software (Rambaut 2008).

\section{RESULTS}

\section{Disease signs and bacteriology}

Lake sturgeon mortality events at GRH or UMAAHF during 2009 to 2010 (Fig. 2) were characterized by fish inappetence, anorexia and erratic behavior such as swimming with the tail up and head down in the water column, unstable equilibrium and gasping near the surface of the water. Petechial haemorrhaging was present at the base of the pectoral and anal fins as well as around the mouth area in some of the fish. Dark red gills with pinpoint foci, accumulations of gill mucus and exaggerated gill movement were also noted. However, bacterial growth was not observed on media inoculated with samples derived from moribund fish.

\section{Virology and PCR}

Namao virus was detected by cPCR amplification of a $219 \mathrm{bp}$ MCP DNA fragment in almost $94 \%$ (59 of 63) of those samples in this study derived from dead or moribund lake sturgeon originating from the Nelson or Winnipeg Rivers (Table 4). The ginF and

Table 4. Diagnostic test results (no. positive/no. tested) from samples taken during disease outbreaks in the 2008 and 2009 year classes of juvenile lake sturgeon, sourced from the Winnipeg (WR) and Nelson River (NR), and raised at Grand Rapids Hatchery (GRH) and the University of Manitoba Aquatic Animal Holding Facility (UMAAHF). cPCR: conventional polymerase chain reaction; $\mathrm{qPCR}$, quantitative PCR. See Tables $1 \& 2$ for virus abbreviations

\begin{tabular}{|lcccc|}
\hline \multirow{2}{*}{$\begin{array}{l}\text { Molecular } \\
\text { test method }\end{array}$} & 2008 & \multicolumn{3}{c|}{ 2009 } \\
\cline { 3 - 5 } & UMAAHF & \multicolumn{2}{c|}{ GRH } & UMAAHF \\
& WR & NR & WR & WR \\
\hline NV cPCR & $7 / 8$ & $3 / 3$ & $35 / 37$ & $14 / 15$ \\
WSIV qPCR & $0 / 8$ & $0 / 3$ & $0 / 35$ & $0 / 12$ \\
MRSIV qPCR & $0 / 8$ & $0 / 3$ & $0 / 35$ & $0 / 12$ \\
\hline
\end{tabular}


glaR primer pair yielded a cPCR product of both the expected size (data not shown) and sequence (described below). Neither the WSIV MCP-based nor
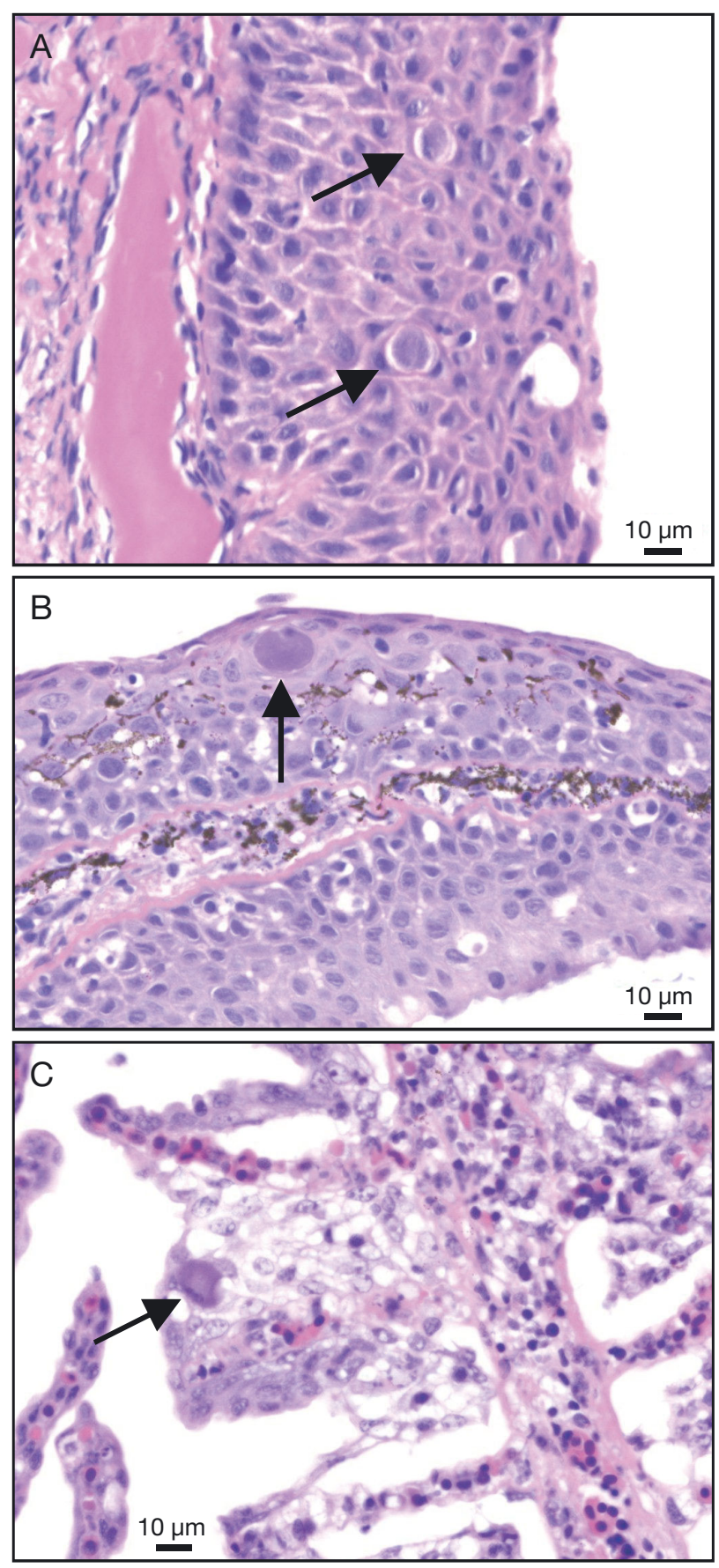

Fig. 3. Acipenser fulvescens. Light photomicrographs of H\&E stained epithelial tissue sections from moribund juvenile lake sturgeon. (A) Skin tissue from Winnipeg River lake sturgeon (2008 year class) housed at the University of Manitoba Aquatic Animal Holding Facility. (B) Skin and (C) gill tissue from Winnipeg River lake sturgeon (2009 year class) housed at Grand Rapids Hatchery. Large amphophilic intracytoplasmic inclusions are evident (arrows) the MRSIV serpin-based qPCR tests were able to detect Namao virus in the same samples. Our Namao virus MCP-based cPCR test, which also detects WSIV (including artificially synthesized DNA encoding the WSIV MCP), MRSIV and a recently diagnosed virus from white sturgeon cultured in British Columbia, will be described in detail elsewhere. The 7 samples collected in December 2008 prior to the 2009 outbreak at UMAAHF tested negative for the presence of Namao virus nucleic acid using the ginF/glaR cPCR assay.

Inoculation of primary lake sturgeon cell lines (LSGI or LSGO) with tissue homogenates shown to be positive for Namao virus by CPCR did not result in noticeable CPE after 21 to $60 \mathrm{~d}$ of observation or blind passage on the same cell lines. However, some of the culture fluid containing suspended lake sturgeon cells from CPE-negative monolayers tested positive for Namao virus after the first passage (the second passage was not tested by CPCR). The cells from white sturgeon (WSSK-1, WSS-2), Chinook salmon Oncorhynchus tshawytscha (CHSE-214) and common carp Cyprinus carpio (EPC) did not display CPE within $21 \mathrm{~d}$ of inoculation with tissue samples derived from the same populations of lake sturgeon. The WSS-2 cells, inoculated with 4 samples, 2 of which tested positive for Namao virus by $\mathrm{CPCR}_{\text {, }}$ tested negative by the same assay for the presence of Namao virus after a single passage. The cPCR did not amplify the $219 \mathrm{bp}$ DNA product from any of the naïve cell lines used in this study.

\section{Histology and TEM}

Low numbers of hypertrophic cells were found in H\&E stained histological samples of gill and skin epithelia tissues from moribund lake sturgeon (Fig. 3). The cytomegalic cells were scattered throughout the epithelial layer of the gill lamellae and appeared to contain granular, cytoplasmic inclusion bodies often associated with iridovirus-like infections of white-, pallid- and shovelnose sturgeon. Histological sections from the same fish did not show evidence of significant changes in kidney, heart, brain lower intestine, pancreas or nervous tissues. Enumeration of inclusion bodies in longitudinal sections of 14 juvenile lake sturgeon collected from GRH in May 2009 indicated a tropism of the virus for epithelial cells of the integument (Table 5).

Examination of cytomegalic cells within lake sturgeon gill lamellae epithelium by TEM revealed the presence of icosahedral-shaped virus particles in the 
Table 5. Acipenser fulvescens. Enumeration of inclusion bodies (average no.) in longitudinal sections of moribund or mildly infected juvenile lake sturgeon from the Winnipeg River (WR) and Nelson River (NR). ND: not done

\begin{tabular}{|c|c|c|c|}
\hline \multirow[t]{3}{*}{ Site } & \multicolumn{3}{|c|}{ Average number of inclusion bodies } \\
\hline & \multicolumn{2}{|c|}{ Moribund sturgeon } & \multirow{2}{*}{$\begin{array}{c}\text { Juvenile sturgeon } \\
\text { WR } \\
(\mathrm{n}=5)\end{array}$} \\
\hline & $\begin{array}{c}\text { WR } \\
(n=5)\end{array}$ & $\begin{array}{c}\text { NR } \\
(\mathrm{n}=4)\end{array}$ & \\
\hline Nasal pits & 8.5 & 4 & 1 \\
\hline Snout & 3.5 & 2.25 & 0 \\
\hline Mouth & 4.3 & 1.75 & 0 \\
\hline Gill & 3.6 & 3.5 & 0.4 \\
\hline \multicolumn{4}{|l|}{ Epidermis } \\
\hline Cranial & 14.1 & 8.45 & 2.0 \\
\hline Abdominal - mid & 9.4 & 3.5 & 0.8 \\
\hline Abdominal - distal & 4.5 & ND & 0.5 \\
\hline \multicolumn{4}{|l|}{ Fins } \\
\hline Pectoral & 12.3 & 2.75 & 0 \\
\hline Dorsal & 17 & ND & ND \\
\hline Pelvic & 4.5 & 3.5 & 0 \\
\hline
\end{tabular}

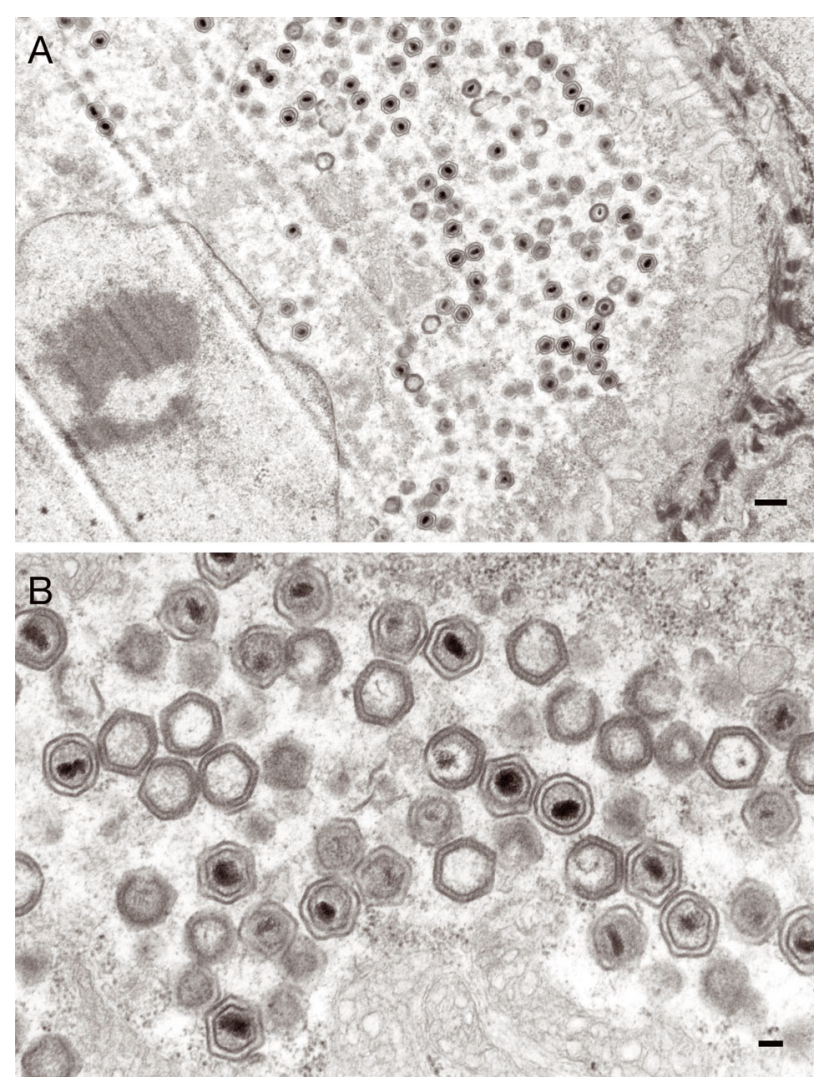

Fig. 4. Acipenser fulvescens. Transmission electron micrographs of cytoplasmic hexagonal virus particles in epithelial cells of gill lamellae from Winnipeg River, juvenile lake sturgeon (2008 year class) held at the University of Manitoba Aquatic Animal Holding Facility. Intact virions were 225 to $263 \mathrm{~nm}(\mathrm{n}=18$, mean $\pm \mathrm{SD}=242 \pm 11 \mathrm{~nm})$ in diameter, as measured from side to side, and 263 to $300 \mathrm{~nm}$ from vertex to vertex $(\mathrm{n}=18$, mean $\pm \mathrm{SD}=282 \pm 13 \mathrm{~nm})$. Scale bars: $(\mathrm{A})$ $500 \mathrm{~nm}$; (B) $100 \mathrm{~nm}$ cell cytoplasm (Fig. 4). Some of the virions contained a condensed bar-shaped core. Amorphous virus-like particles as well as empty or incomplete capsids were also evident. Intact virions had 2 capsids and were approximately $242 \mathrm{~nm}$ in diameter as measured from side to side and $282 \mathrm{~nm}$ vertex to vertex (Fig. 4, Table 1).

\section{MCP alignment and analysis}

We captured an estimated 95 to $96 \%$ of the Namao virus MCP open reading frame or its inferred amino acids based upon comparison with the WSIV MCP sequences (Fig. 5, Table 2; GenBank accession number JX155659). The identity of the amino acids shared between Namao virus and WSIV was $83.5 \%$ (Table 6). Namao virus and WSIV MCP sequences shared the highest E-value (7e-99) with viruses grouped in the Mimiviridae family and to a lesser extent Phycodnaviridae (3E-46) and Iridoviridae (1e15) families, according to BLASTP analysis (Altschul et al. 1990, 1997). Conserved domains identified within the Namao virus MCP are presented in Fig. 5.

\section{Phylogenetic analyses}

Namao virus and WSIV grouped more closely to each other than to any of the other viruses based upon phylogenetic analysis using the MCP amino acid sequence (Fig. 6). This was the case for tree reconstructions employing Bayesian inference (Huelsenbeck \& Ronquist 2001, Ronquist \& Huelsenbeck 2003) or maximum-likelihood methods (Guindon et al. 2010). The sturgeon viruses appeared in the Mimiviridae and Phycodnaviridae lineage but partitioned into the Mimiviridae clade. Both sturgeon viruses were clearly separate from and were not members of the Irido-Asco-MV clade.

Within the Mimiviridae family, the 2 megaviruses (proposed genera) and mimiviruses clustered together and shared a common ancestor with the mamavirus, $\mathrm{CroV}$ and sturgeon viruses. While this relationship was similar using either method of tree reconstruction, the relative branching topography for the latter 3 viruses was different. In the maximum-likelihood tree, CroV and mamavirus formed a lineage together that split from the sturgeon viruses after the node representing the ancestral Mimiviridae progenitor. However, the bootstrap values were too low (221/ 1000) to resolve the phylogenetic position of the sturgeon viruses relative to $\mathrm{CroV}$ and mamavirus. 


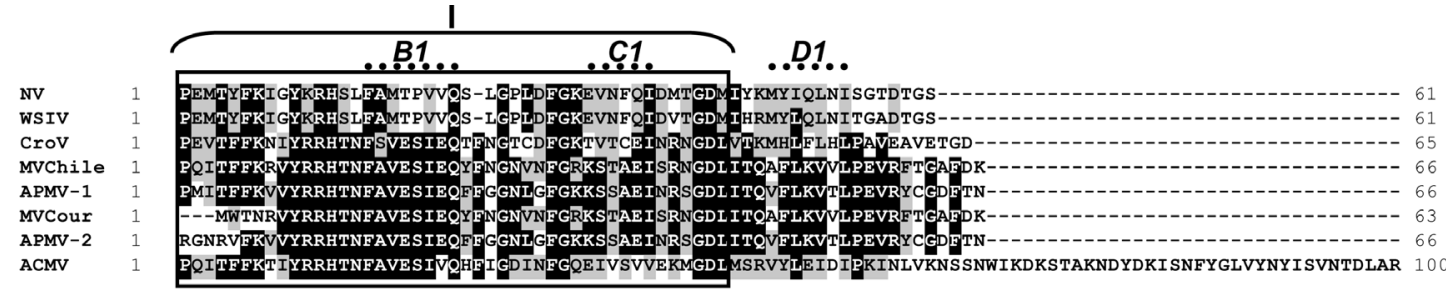

NV
WSIV
Crov
MVChile
APMV-1
MVCour
APMV-2
ACMV
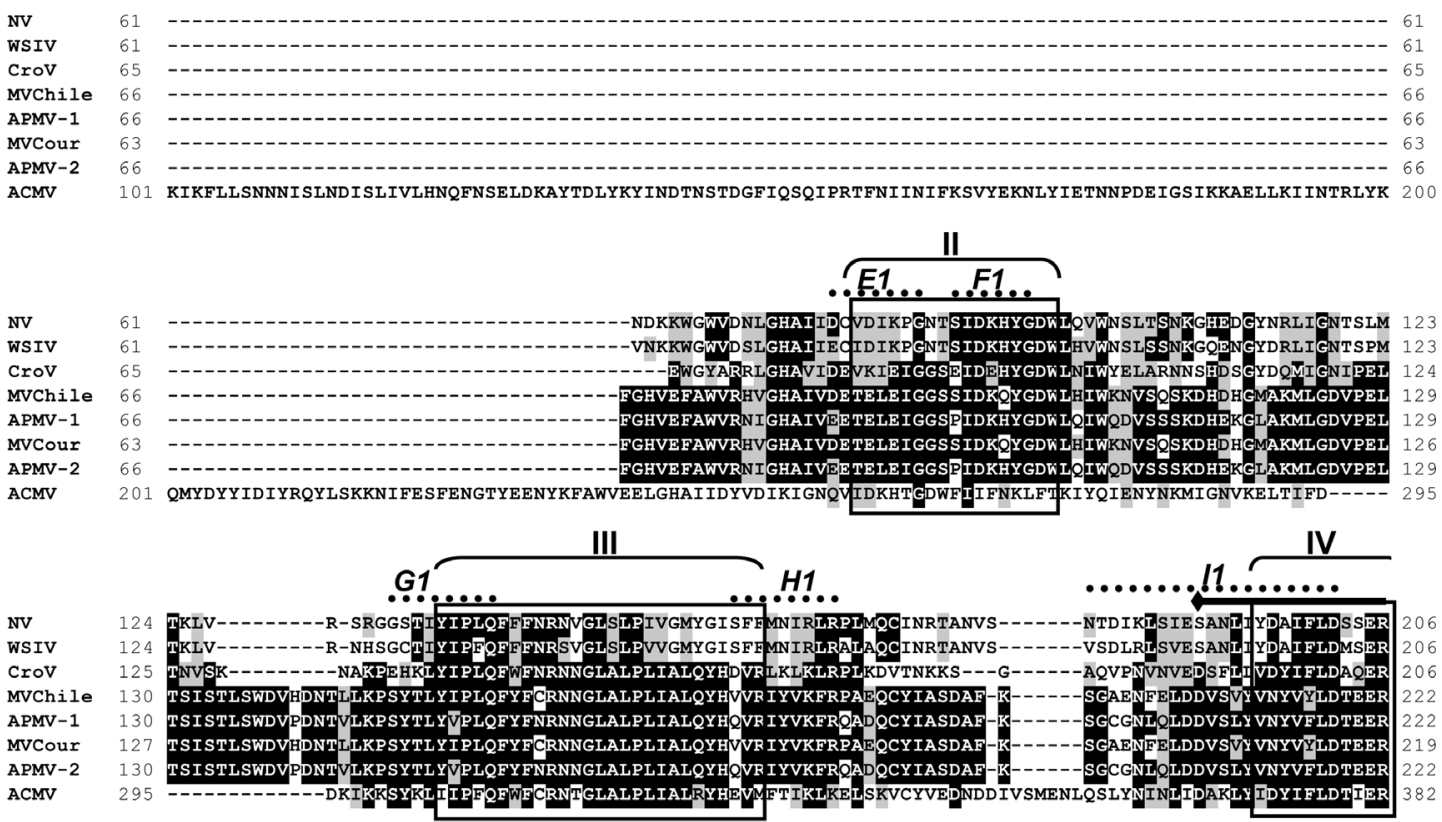

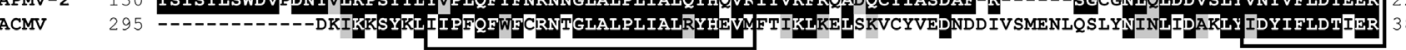

NV

WSIV

Crov

MvChile

APMV-1

MVCour

APMV-

ACMV
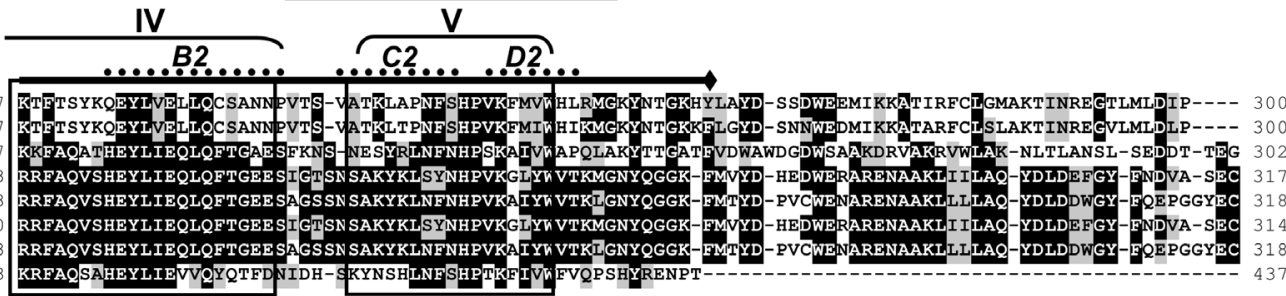

NV
WSIV
CroV
MVChile
APMV-1
MVCour
APMV-2
ACMV

NS

Crov

MVChil

APMV-1

MVCour

APMV - 2

ACMV

NV

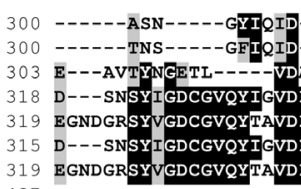

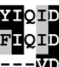

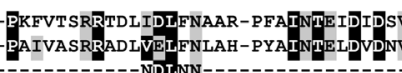

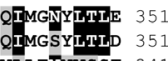
A

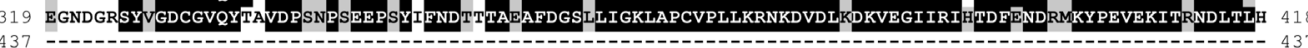

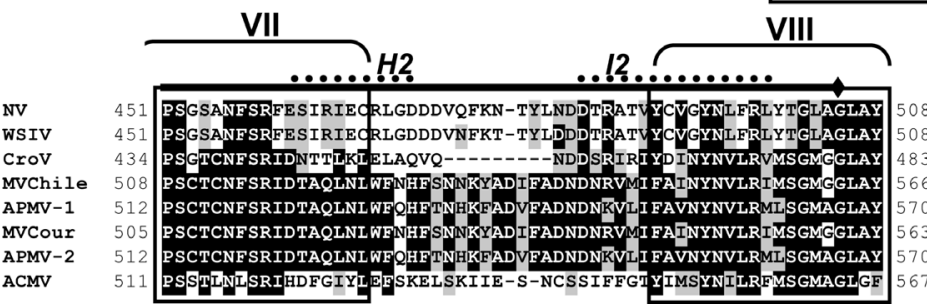


Fig. 5. Alignment of major capsid protein (MCP) sequences from 8 viruses found to cluster together in the phylogenetic tree presented in Fig. 6. The MCP sequences were trimmed to the first and last amino acids aligning with the $\mathrm{N}$ and $\mathrm{C}$ terminal ends, respectively, of the Namao virus (NV) MCP fragment targeted by primers from the present study. Identical amino acid residues shared by 2 or more sequences are shaded black whereas similar residues are shaded grey. The numbers preceding and following the alignments indicate the positions of the first and last residues of the aligned regions in the corresponding protein sequences. Bars above the sequence delineate the conserved nucleo-cytoplasmic large DNA virus domains identified in the NV MCP through the Conserved Domain Database and National Center for Biotechnology Information's Conserved Domain Search service. The beta strands predicted in the first and second jelly-roll motifs are designated B1 to I1 and B2 to I2, respectively. The 8 conserved capsid domains reported by Larsen et al. (2008) for viruses classified as members of family Phycodnaviridae are boxed and labelled I to VIII. Virus abbreviations are defined in Table 2

Table 6. Analysis of the major capsid protein from Namao virus and other nucleo-cytoplasmic large DNA viruses. Data are values or ranges of \% identity/\% similarity of amino acid sequences. WSIV: white sturgeon iridovirus; IAMV: Irido-ascoMarseilleviruses

\begin{tabular}{|c|c|c|c|c|c|}
\hline \multirow[t]{2}{*}{ Virus taxon/clade } & \multicolumn{2}{|c|}{ Sturgeon viruses } & \multirow{2}{*}{$\begin{array}{l}\text { Mimi-mama- } \\
\text { megaviruses }\end{array}$} & \multirow[t]{2}{*}{ Phycodnaviruses } & \multirow[t]{2}{*}{ IAMV } \\
\hline & Namao virus & WSIV & & & \\
\hline \multirow[t]{2}{*}{ WSIV } & 83.5 & & & & \\
\hline & 94.1 & & & & \\
\hline \multirow[t]{2}{*}{ Mimi-mama-megaviruses } & $20.6-34$ & $20.8-32$ & $22.1-99.1$ & & \\
\hline & $41.6-54.7$ & $40-54.1$ & $43.5-99.1$ & & \\
\hline \multirow[t]{2}{*}{ Phycodnaviruses } & $20.5-29.8$ & $19.1-30.2$ & $20.3-42.3$ & $25-77.4$ & \\
\hline & $40.2-53.2$ & $38.4-51.9$ & $37.4-60.0$ & $39.1-86.7$ & \\
\hline \multirow[t]{2}{*}{ IAMV } & $17.8-21.6$ & $17.7-20.9$ & $15.4-22.2$ & $16.8-26$ & $27.7-60.1$ \\
\hline & $35.8-37.4$ & $33.9-38.0$ & $29.8-40.0$ & $32.3-48.2$ & $47.2-73.4$ \\
\hline \multirow[t]{2}{*}{ Asfarviridae } & 17.8 & 16.9 & $15.8-17.7$ & $14.4-18$ & $14.5-17.7$ \\
\hline & 33.9 & 32.9 & $30.7-38.3$ & $25.6-34.6$ & $29-33.2$ \\
\hline
\end{tabular}

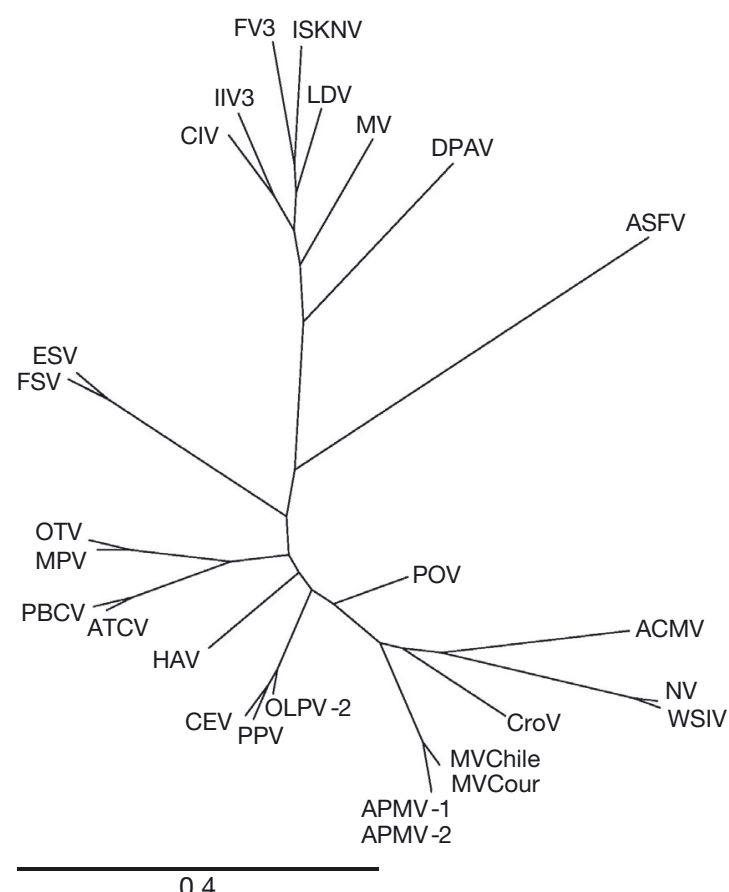

Fig. 6. Phylogenetic tree reconstruction of the major capsid protein (MCP) of 27 nucleo-cytoplasmic large DNA viruses, including Namao virus (NV) and white sturgeon iridovirus (WSIV). The tree was generated using Bayesian inference (BI) from MCP sequences with nodes labeled with BI posterior probabilities (Materials and methods). Abbreviations of other viruses and accession numbers are shown in Table 2

\section{DISCUSSION}

We have discovered a new virus, Namao virus, associated with die-offs among juvenile lake sturgeon being reared as part of a conservation stocking program for endangered populations of sturgeon from the Nelson and Winnipeg rivers, MB. The ultrastructure of Namao virus, including its relatively large size (242 nm), was consistent with those reported for WSIV, MRSIV and a virus from Russian sturgeon Acipenser guldenstadi (Hedrick et al. 1990, 1992, Adkison et al. 1998, Kurobe et al. 2011). The virus also displayed a tropism for the integument of the body and gills and caused cellular abnormalities consistent with pathognomonic changes used to presumptively diagnose sturgeon NCLDVs. This information, in conjunction with the phylogenetic relationship and tree topology we observed, suggests that Namao virus and WSIV as well as other sturgeon NCLDVs (authors' unpubl. results) share a common evolutionary past and might be members of the Mimiviridae or a new, as yet, unrecognized virus family.

Further tests will be required to establish causality between infection with Namao virus and lake sturgeon morbidity and mortality. However, observations in this study point to this effect and the link is coherent with our general understanding of sturgeon 
NCLDVs. Apart from the pathognomonic changes we observed, the virus was present in almost all the fish samples $(93.6 \%)$ that were linked to the die-offs and in a suitable condition for analysis by CPCR. Initial attempts to isolate the virus in pure culture on white sturgeon cell lines were unsuccessful. This is similar to MRSIV (Kurobe et al. 2011) and some isolates of WSIV (Hedrick et al. 1990, Drennan et al. 2006). We were able to detect Namao virus, although weakly, by cPCR when suspect tissues were inoculated and then incubated for prolonged periods on primary lake sturgeon cell lines but without evidence of CPE. This could mean that the cells supported virus replication or that the virus present in the original inoculum was being detected. The difficulty we encountered culturing the virus has prompted our interest in ascertaining whether Namao virus and related sturgeon NCLDVs might be amenable to propagation on cultured amoebae similar to members of the family Mimiviridae (La Scola et al. 2003, 2008) or the unclassified Marseillevirus (Boyer et al. 2009). This follows from the proposal that amoeba function as melting pots for these and possibly other NCLDVs (Boyer et al. 2009). Successful culturing of Namao virus would open a convenient avenue for examination of the disease dynamics and enable fulfillment of the criteria required to establish causality of disease (Koch 1890, Hill 1965, Evans 1976).

WSIV and MRSIV display signs of a complex lifecycle that can manifest as an acute or chronic infection in juvenile sturgeon depending on rearing conditions during the first year of growth (Hedrick et al. 1990, 1992, LaPatra et al. 1994, 1996, Watson et al. 1998a,b, Drennan et al. 2005, 2006, Kurobe et al. 2011). Our observations suggest that Namao virus is similar in this respect. We suspect that the die-offs at UMAAHF and GRH signaled the switch between the chronic and acute phases of the virus life-cycle. In this scenario, the fish could have been infected either horizontally or vertically at the time of fertilization or subsequently by horizontal transmission prior to transport to UMAAHF. However, we cannot rule out the possibility that filtered and dechlorinated municipal water at UMAAHF was the source of infection in lake sturgeon at the facility, especially since Marseillevirus, mamavirus and mimivirus were all isolated from samples of water collected from cooling towers in Europe (La Scola et al. 2003, 2008, Boyer et al. 2009). From a parsimonious standpoint, however, it seems more likely that the fish were infected prior to transport to UMAAHF. This would point to infection occurring in the 2008 year class of Winnipeg River lake sturgeon at the broodstock collection site
(Slave Falls) or subsequently at Pinawa Hatchery (site of larval rearing) which used untreated water from the Winnipeg River. The source of the virus at GRH in the 2009 year class of Nelson River and Winnipeg River is less clear and will require completion of our ongoing epidemiological study. In addition to the sources already noted, the virus at GRH could have been introduced from the Nelson River lake sturgeon or the Saskatchewan River which supplies water to the hatchery.

The cumulative mortality in lake sturgeon populations harboring Namao virus reached a high level, approaching $100 \%$ in the 2009 Nelson River year class held at GRH. This is similar to the level of mortality caused by WSIV in white sturgeon or MRSIV in pallid or shovelnose sturgeon naturally exposed to the virus (Hedrick et al. 1990, 1992, Kurobe et al. 2011). Qualitatively, the kinetics of the die-offs were distinct when comparisons were made between UMAAHF and GRH but the outcome was similar. The die-offs at UMAAHF occurred over the course of 2 to 4 wk whereas those at GRH occurred over the course of approximately 1 mo in fish derived from the Nelson River and 6 mo in the Winnipeg River stock. Such variation in mortality kinetics is not without precedent among sturgeon NCLDV infections, and has been attributed to risk factors including handling, stocking density, and water conditions (LaPatra et al. 1994, 1996, Watson et al. 1998a, Drennan et al. 2005, 2006). Each of these factors was different between the 2 facilities as were the stocks of fish held at GRH. Specific studies designed to assess the role or influence these variables have on Namao virus disease dynamics could be used to avoid or minimize outbreaks caused by the virus in hatcheries. Further, it will be important to control viral trafficking of Namao virus in lake sturgeon through the management of factors related to virus source, prevalence and transmission much like what has already been accomplished for WSIV in white sturgeon through the Kootenai River White Sturgeon Conservation Aquaculture Program (LaPatra et al. 1999, KTOI 2007).

In the present study, 7 fish collected 2 mo prior to disease onset at UMAAHF tested negative for Namao virus by cPCR. The absence of detection does not rule out the presence of Namao virus in these fish. Especially given the limited sensitivity of the test compared to qPCR, absence of verification by a different test method such as cell culture, and the possibility that the virus might persist at extremely low levels as a localized chronic infection in asymptomatic fish. In addition, differences in the ability to 
detect sturgeon NCLDVs might reflect the choice of tissues sampled or differences in disease susceptibility of the host (Kwak et al. 2006, Drennan et al. 2007, Kurobe et al. 2010). The outbreaks at UMAAHF were temporally asynchronous but acute, indicating that a large percentage of the fish were either harboring the virus at the onset of mortality or that the fish were exposed to a high dose of virus on 4 separate occasions. Again, the latter would indicate that an occasional large amount of virus was present in the treated municipal water or that a highly contaminated fomite was present and led to infection of fish in the different tanks on 4 different occasions. None of these possibilities can be ruled out from having occurred in the present study but, as we mentioned earlier, the presence of the virus in treated, municipal water seems unlikely, though not impossible. In fact, Drennan et al. (2006) reported that the accidental introduction of as little as $100 \mathrm{ml}$ of Kootenai River water resulted in fish testing positive for WSIV during the course of an experiment conducted in tanks receiving municipal water.

The classification of sturgeon NCLDVs might become clearer with our phylogenetic analysis coupled with commonalities observed among their life-cycles. The general topology of the phylogenetic tree we reconstructed was strongly supported by Bayesian inference analysis and was consistent with virtually all those trees reported in the literature pertaining to NCLDVs regardless of the method used to reconstruct the tree or whether the tree was generated with the MCP or concatamers of conserved NCLDV protein sequences (Tidona \& Darai 2000, Raoult et al. 2004, Iyer et al. 2006, Larsen et al. 2008, Monier et al. 2008, Boyer et al. 2009, Yutin et al. 2009, Fischer et al. 2010, Koonin \& Yutin 2010, Arslan et al. 2011). It must be kept in mind that our phylogenetic tree was reconstructed using only the $\mathrm{MCP}$, one of the 5 nucleo-cytoplasmic virus orthologous genes (Yutin et al. 2009). The genomes of these giant viruses possess a complex repertoire of genes from various origins including viruses, bacteria and eukaryotes, and reflect a rich evolutionary history (Filée 2009) and it is possible that the genome of Namao virus and related sturgeon NCLDVs, aside from their MCP genes, are more distantly related to the Mimiviridae and Phycodnaviridae families than indicated by our results. For instance, there is some evidence of gene exchange between the distantly related Marseillevirus and mimivirus (Boyer et al. 2009). Our ongoing metagenomic studies in conjunction with the work of others may provide further insight into the taxonomy of these viruses.
Our results indicate that Namao virus and WSIV shared a common lineage with $\mathrm{CroV}$ and mamavirus within the Mimiviridae family. The close phylogenetic relationship between the latter 2 viruses was reported previously by Fischer et al. (2010). The genome of mamavirus is approximately 1.6-fold larger than that of CroV. In this context, the sturgeon NCLDVs' capsid diameters were most similar to that of CroV in size and were approximately half the size of that for megaviruses, the largest known members of the family Mimiviridae. The Namao virus and WSIV MCPs both contained 2 conserved NCLDV capsid domains (Marchler-Bauer et al. 2011) separated by an insertion of approximately 135 or 91 amino acids, respectively (Fig. 5, Table 2). This insertion was similar to that described for the APMV-1 capsid protein 1 (Azza et al. 2009) and like the mimivirus, this insertion occurred in the predicted DE loop of the second jelly roll along the sturgeon virus capsid proteins. The Namao virus and WSIV MCPs also contained the 8 conserved capsid domains reported by Larsen et al. (2008) for viruses classified as members of the family Phycodnaviridae. The mamavirus, like most of the viruses belonging to the Phycodnaviridae and all of the iridoasco-MV-asfarviruses listed in Table 2, did not contain this insertion and instead had a single, fused conserved capsid domain. Further, the mamavirus MCP contained an N-terminal insertion of 162 amino acids between MCP Domains 1 and 2 of the phycodnavirus-like capsid proteins.

If Namao virus and related sturgeon viruses are indeed members of the Mimiviridae family, then the host range of this group of viruses would be extended from unicellular eukaryotes to lower vertebrates. Likewise, the names as well as the taxonomic grouping of suspected 'irido-like' sturgeon NCLDVs will likely require amendment based on the results of this study. We believe this might be the case regardless of the final taxonomic designation of the sturgeon NCLDVs because comparison of iridovirus MCP sequences to that of Namao virus and WSIV reveal fundamental differences in their evolutionary relationship.

Acknowledgements. This work was supported in part by Manitoba Hydro. L. Burton generated the electron microscopy images and J. Neufeld identified icosahedral-shaped particles as iridoviruses at the Canadian Food Inspection Agency, National Centre for Foreign Animal Disease. S. Mead supplied the white sturgeon skin and spleen cell lines to S.C.C. and conducted some of the virological assays for the Freshwater Fisheries Society of BC (Duncan, BC) and J. Robinson performed some of the molecular assays for the Animal Health Centre, Ministry of Agriculture (Abbotsford, BC). A. Lewin created the maps. 


\section{LITERATURE CITED}

Adkison MA, Cambre M, Hedrick RP (1998) Identification of an iridovirus in Russian sturgeon (Acipenser guldenstadi) from Northern Europe. Bull Eur Assoc Fish Pathol 18:29-32

Altschul SF, Gish W, Miller W, Myers EW, Lipman DJ (1990) Basic local alignment search tool. J Mol Biol 215:403-410

Altschul SF, Madden TL, Schaffer AA, Zhang J, Zhang A, Miller W, Lipman DF (1997) Gapped BLAST and PSIBLAST: a new generation of protein database search programs. Nucleic Acids Res 25:3389-3402

> Arslan D, Legendre M, Seltzer V, Abergel C, Claverie JM (2011) Distant Mimivirus relative with a larger genome highlights the fundamental features of Megaviridae. Proc Natl Acad Sci USA 108:17486-17491

> Azza S, Cambillau C, Raoult D, Suzan-Monti M (2009) Revised Mimivirus major capsid protein sequence reveals intron-containing gene structure and extra domain. BMC Mol Biol 10:39-46

> Boyer M, Yutin N, Pagnier I, Barrassi L and others (2009) Giant Marseillevirus highlights the role of amoebae as a melting pot in emergence of chimeric microorganisms. Proc Natl Acad Sci USA 106:21848-21853

> Boyer M, Azza S, Barrassi L, Klose T and others (2011) Mimivirus shows dramatic genome reduction after intraamoebal culture. Proc Natl Acad Sci USA 108: 10296-10301

Campanella JJ, Bitincka L, Smalley J (2003) MatGAT: an application that generates similarity/identity matrices using protein or DNA sequences. BMC Bioinformatics 4:29-32

> Chen F, Suttle CA, Short SM (1996) Genetic diversity in marine algal virus communities as revealed by sequence analysis of DNA polymerase genes. Appl Environ Microbiol 62:2869-2874

Claverie JM, Ogata H, Audic S, Abergel C, Suhre K, Journier PE (2006) Mimivirus and the emerging concept of 'giant' virus. Virus Res 117:133-144

Cock JM, Sterck L, Rouzé P, Scornet D and others (2010) The Ectocarpus genome and the independent evolution of multicellularity in brown algae. Nature 465:617-621

> Colson P, Yutin N, Shabalina SA, Robert C and others (2011) Viruses with more than 1000 genes: Mamavirus, a new Acanthamoeba polyphaga mimivirus strain, and reannotation of mimivirus genes. Genome Biol Evol 3:737-742

COSEWIC (Committee on the Status of Endangered Wildlife in Canada) (2011) Canadian wildlife species at risk. Available at www.cosewic.gc.ca/eng/sct0/rpt/rpt_csar _e.cfm (accessed 17 Oct 2011)

> Delhon G, Tulman ER, Afonso CL, Lu Z and others (2006) Genome of invertebrate iridescent virus type 3 (mosquito iridescent virus). J Virol 80:8439-8449

Di Tommaso P, Moretti S, Xenarios I, Orobitg M and others. (2011) T-Coffee: a web server for the multiple sequence alignment of protein and RNA sequences using structural information and homology extension. Nucleic Acids Res 39 (Suppl 2):W13-W17

> Drennan JD, Ireland S, LaPatra SE, Grabowski L, Carrothers TK, Cain KD (2005) High-density rearing of white sturgeon Acipenser transmontanus (Richardson) induces white sturgeon iridovirus disease among asymptomatic carriers. Aquacult Res 36:824-827

> Drennan JD, LaPatra SE, Siple JT, Ireland S, Cain KD (2006) Transmission of white sturgeon iridovirus in Kootenai
River white sturgeon Acipenser transmontanus. Dis Aquat Org 70:37-45

> Drennan JD, LaPatra SE, Samson CA, Ireland S, Eversman KF, Cain KD (2007) Evaluation of lethal and non-lethal sampling methods for the detection of white sturgeon iridovirus infection in white sturgeon, Acipenser transmontanus (Richardson). J Fish Dis 30:367-379

Evans AS (1976) Causation and disease: the Henle-Koch postulates revisited. Yale J Biol Med 49:175-195

> Fijan N, Sulimanovi D, Bearzotti M, Muzini D and others (1983) Some properties of the Epithelioma papulosum cyprini (EPC) cell line from carp Cyprinus carpio. Ann Inst Pasteur Virol 134:207-220

Filée J (2009) Lateral gene transfer, lineage-specific gene expansion and the evolution of nucleo cytoplasmic large DNA viruses. J Invertebr Pathol 101:169-171

Fischer MG, Allen MJ, Wilson WH, Suttle CA (2010) Giant virus with a remarkable complement of genes infects marine zooplankton. Proc Natl Acad Sci USA 107: 19508-19513

Fitzgerald LA, Graves MV, Li X, Feldblyum T, Nierman WC, Van Etten JL (2007) Sequence and annotation of the $369-\mathrm{kb}$ NY-2A and the 345-kb AR158 viruses that infect Chlorella NC64A. Virology 358:472-484

Fuhrman JA (1999) Marine viruses and their biogeochemical and ecological effects. Nature 399:541-548

> Georgiadis MP, Hedrick RP, Johnson WO, Yun S, Gardner IA (2000) Risk factors for outbreaks of disease attributable to white sturgeon iridovirus and white sturgeon herpesvirus-2 at a commercial sturgeon farm. Am J Vet Res 61:1232-1240

> Georgiadis MP, Hedrick RP, Carpenter TE, Gardner IA (2001) Factors influencing transmission, onset and severity of outbreaks due to white sturgeon iridovirus in a commercial hatchery. Aquaculture 194:21-35

> Guindon S, Dufayard JF, Lefort V, Anisimova M, Hordijk W, Gascuel O (2010) New algorithms and methods to estimate maximum-likelihood phylogenies: assessing the performance of PhyML 3.0. Syst Biol 59:307-321

Hall TA (1999) BioEdit: a user-friendly biological sequence alignment editor and analysis program for Windows 95/98/NT. Nucl Acids Symp Ser 41:95-98.

> He JG, Deng M, Weng SP, Li Z and others (2001) Complete genome analysis of the mandarin fish infectious spleen and kidney necrosis iridovirus. Virology 291:126-139

> Hedrick RP, Groff JM, McDowell T, Wingfield WH (1990) An iridovirus infection of the integument of the white sturgeon Acipenser transmontanus. Dis Aquat Org 8:39-44

Hedrick RP, McDowell TS, Rosemark R, Aronstein D, Lannan CN (1991) Two cell lines from white sturgeon. Trans Am Fish Soc 120:528-534

Hedrick RP, McDowell TS, Groff JM, Yun S, Wingfield WH (1992) Isolation and some properties of an iridovirus-like agent from white sturgeon Acipenser transmontanus. Dis Aquat Org 12:75-81

- Hill AB (1965) The environment and disease: association or causation. Proc R Soc Med 58:295-300

> Holopainen R, Ohlemeyer S, Schütze H, Bergmann SM, Tapiovaara H (2009) Ranavirus phylogeny and differentiation based on major capsid protein, DNA polymerase and neurofilament triplet H1-like protein genes. Dis Aquat Org 85:81-91

> Huelsenbeck JP, Ronquist F (2001) MRBAYES: Bayesian inference of phylogeny. Bioinformatics 17:754-755

Iyer LM, Aravind L, Koonin EV (2001) Common origin of 
four diverse families of large eukaryotic DNA viruses. J Virol 75:11720-11734

Iyer LM, Balaji S, Koonin EV, Aravind L (2006) Evolutionary genomics of nucleo-cytoplasmic large DNA viruses. Virus Res 117:156-184

Jakob NJ, Muller K, Bahr U, Darai G (2001) Analysis of the first complete DNA sequence of an invertebrate iridovirus: coding strategy of the genome of Chilo iridescent virus. Virology 286:182-196

Koch R (1890) An address on bacteriological research. BMJ 2:380-383

Koonin EV, Yutin N (2010) Origin and evolution of eukaryotic large nucleo-cytoplasmic DNA viruses. Intervirology 53:284-292

KTOI (Kootenai Tribe of Idaho) (2007) Kootenai River White Sturgeon Conservation Aquaculture Program, 19902007, 2nd edn (Eds: Beamesderfer R, Anders P). Cramer Fish Sciences, Bonners Ferry, ID

Kurobe T, Kwak KT, MacConnell E, McDowell TS, Mardones FO, Hedrick RP (2010) Development of PCR assays to detect iridovirus infections among captive and wild populations of Missouri River sturgeon. Dis Aquat Org 93:31-42

Kurobe T, MacConnell E, Hudson C, Mardones FO, Hedrick RP (2011) Iridovirus infections among Missouri River sturgeon: initial characterization, transmission and evidence for establishment of a carrier state. J Aquat Anim Health 23:9-18

Kwak KT (2006) Improved detection and further characterization of white sturgeon iridovirus: insights into pathogenesis and exclusion from the family Iridoviridae. $\mathrm{PhD}$ thesis, University of California, Davis, CA

> Kwak KT, Gardner IA, Farver TB, Hedrick RP (2006) Rapid detection of white sturgeon iridovirus (WSIV) using a polymerase chain reaction (PCR) assay. Aquaculture 254:92-101

> La Scola B, Audic S, Robert C, Jungang L and others (2003) A giant virus in amoebae. Science 299:2033

La Scola B, Desnues C, Pagnier I, Robert C and others (2008) The virophage as a unique parasite of the giant mimivirus. Nature 455:100-104

Lannan CN, Winton JR, Fryer JL (1984) Fish cell lines: establishment and characterization of nine cell lines from salmonids. In Vitro 20:671-676

> LaPatra SE, Groff JM, Jones GR, Munn B and others (1994) Occurrence of white sturgeon iridovirus infections among cultured white sturgeon in the Pacific Northwest. Aquaculture 126:201-210

LaPatra SE, Groff JM, Patterson TL, Shewmaker WK, Casten M, Siple J, Hauck AK (1996) Preliminary evidence of sturgeon density and other stressors on manifestation of white sturgeon iridovirus disease. J Appl Aquacult 6: 51-58

LaPatra SE, Ireland SC, Groff JM, Clemens KM, Siple JT (1999) Adaptive disease management strategies for the endangered population of Kootenai River white sturgeon. Fisheries (Bethesda, Md) 24:6-13

> Larsen JB, Larsen A, Bratbak G, Sandaa RA (2008) Phylogenetic analysis of members of the Phycodnaviridae virus family, using amplified fragments of the major capsid protein gene. Appl Environ Microbiol 74:3048-3057

Legendre M, Santini S, Rico A, Abergel C, Claverie JM (2011) Breaking the 1000-gene barrier for Mimivirus using ultra-deep genome and transcriptome sequencing. Virol J 8:99-104

Marchler-Bauer A, Lu S, Anderson JB, Chitsaz F and others (2011) CDD: a Conserved Domain Database for the functional annotation of proteins. Nucleic Acids Res 39 (Suppl 1): D225-D229

> Monier A, Claverie JM, Ogata H (2008) Taxonomic distribution of large DNA viruses in the sea. Genome Biol 9:R106

> Nagasaki K, Shirai Y, Tomaru Y, Nishida K, Pietrokovski S (2005) Algal viruses with distinct intraspecies host specificities include identical intein elements. Appl Environ Microbiol 71:3599-3607

Notredame C, Higgins DG, Heringa J (2000) T-Coffee: a novel method for fast and accurate multiple sequence alignment. J Mol Biol 302:205-217

Rambaut A (2008) FigTree v1.3.1. Available at http://tree. bio.ed.ac.uk/software/figtree (accessed 21 Dec 2009)

> Raoult D, Audic S, Robert C, Abergel C and others (2004) The 1.2-megabase genome sequence of Mimivirus. Science 306:1344-1350

Raverty S, Hedrick R, Henry J, Saksida S (2003) Diagnosis of sturgeon iridovirus infection in farmed white sturgeon in British Columbia. Can Vet J 44:327-328

Ronquist F, Huelsenbeck JP (2003) MRBAYES 3: Bayesian phylogenetic inference under mixed models. Bioinformatics 19:1572-1574

Sanger F, Nicklen S, Coulson AR (1977) DNA sequencing with chain-terminating inhibitors. Proc Natl Acad Sci USA 74:5463-5467

Schroeder DC, Park Y, Yoon HM, Lee YS and others (2009) Genomic analysis of the smallest giant virus - Feldmannia sp. virus 158. Virology 384:223-232

Stasiak K, Renault S, Demattei MV, Bigot Y, Federici BA (2003) Evidence for the evolution of ascoviruses from iridoviruses. J Gen Virol 84:2999-3009

> Tidona CA, Darai G (2000) Iridovirus homologues of cellular genes-implications for the molecular evolution of large DNA viruses. Virus Genes 21:77-81

Van Etten JL (2011) Another really, really big virus. Viruses 3:32-46

- Van Etten JL, Lane LC, Dunigan DD (2010) DNA viruses: the really big ones (giruses). Annu Rev Microbiol 64:83-99

> Watson LR, Milani A, Hedrick RP (1998a) Effects of water temperature on experimentally-induced infections of juvenile white sturgeon (Acipenser transmontanus) with the white sturgeon iridovirus (WSIV). Aquaculture 166: 213-228

> Watson LR, Groff JM, Hedrick RP (1998b) Replication and pathogenesis of white sturgeon iridovirus (WSIV) in experimentally infected white sturgeon Acipenser transmontanus juveniles and sturgeon cell lines. Dis Aquat Org 32:173-184

> Weynberg KD, Allen MJ, Ashelford K, Scanlan DJ, Wilson WH (2009) From small hosts come big viruses: the complete genome of a second Ostreococcus tauri virus, OtV1. Environ Microbiol 11:2821-2839

> Yau S, Lauro FM, DeMaere MZ, Brown MV and others (2011) Virophage control of antarctic algal host-virus dynamics. Proc Natl Acad Sci USA 108:6163-6168

Yutin N, Wolf YI, Raoult D, Koonin EV (2009) Eukaryotic large nucleo-cytoplasmic DNA viruses: clusters of orthologous genes and reconstruction of viral genome evolution. Virol J 6:223-235

Submitted: July 16, 2012; Accepted: October 25, 2012

Proofs received from author(s): January 23, 2013 